\title{
Some Notes on Ancient Concrete
}

\section{Amelia Carolina Sparavigna ${ }^{1}$}

\author{
${ }^{1}$ Department of Applied Science and Technology, Politecnico di Torino, Italy
}

\begin{abstract}
Concrete is a material composed of coarse granular particles embedded in a binder that glues the particles together. It is commonly believed that the ancient Romans were the first to create and use such material, but this is not true, as we can easily learn from the Latin literature itself. Without any doubt, Romans were able to prepare high-quality hydraulic cement, comparable with the modern Portland cement. In this paper we present some notes on the ancient concrete. From Rome, we will go back in time, showing how the Greeks used it in their Mycenaean royal palaces. The paper continues talking about an Egyptian concrete and ends discussing the use of concrete during Neolithic times.
\end{abstract}

Keywords: Materials Science, History of Science, History of Technology

\section{Introduction}

Concrete is a composite material where we have a coarse granular material, the aggregate, embedded in cement or binder, which is filling the space among the particles of the granular material and gluing them together. One of the most famous ancient concrete structures is the Pantheon in Rome (Fig.1). The Romans used concrete on a large scale, but, after the collapse of the Empire, the use of this material and its related technology were strongly reduced and eventually lost during the Middle Ages.

Two books, the "De Architectura" by Marcus Vitruvius Pollio and the "Naturalis Historia" by Gaius Plinius Secundus, known as Pliny the Elder, give us a precise description of the use of concrete at the beginning of the Roman Empire [1-5]. In fact, these two books are fundamental to investigate the knowledge of materials and their technologies in Rome and deserve a detailed study. Let us focus on the information we can find in these books, to start our notes on the history of concrete. First of all, we will discuss the Roman concrete. Then, we go back in time to the ancient Greeks of the Bronze Age. In Homeric times, as demonstrated by the reports of Schliemann's excavations of Mycenaean archaeological sites, the Greeks used concrete for some floors of the courts of royal palaces. After, we will discuss a disputed hypothesis on an Egyptian concrete. The paper ends with the use of concrete in Neolithic times, demonstrated by some archaeological remains found in the Southern Galilee.

\section{From dust to stone: the Roman concrete}

As previously told, concrete is prepared by the hardening of cement and aggregate. The aggregate could be made of pebbles, ceramic tiles and brick rubbles obtained from the demolition of buildings. The cement is a binder or mortar, which is a substance that sets when mixed with water and then hardens binding together the particles of aggregate. From the third century BC, the ancient Romans were able to prepare high-quality hydraulic cement, suitable for building harbors, because they made it of lime and pozzolana, the volcanic dust of Puteoli [6]. This mixture of pozzolana with the lime produced by heating limestone was called "caementum". "Opus caementicium" was the Roman concrete. Let us note that the Roman caementum has much in common with its modern counterpart, the Portland cement: that is, its composition is very close to that of modern cement [6].

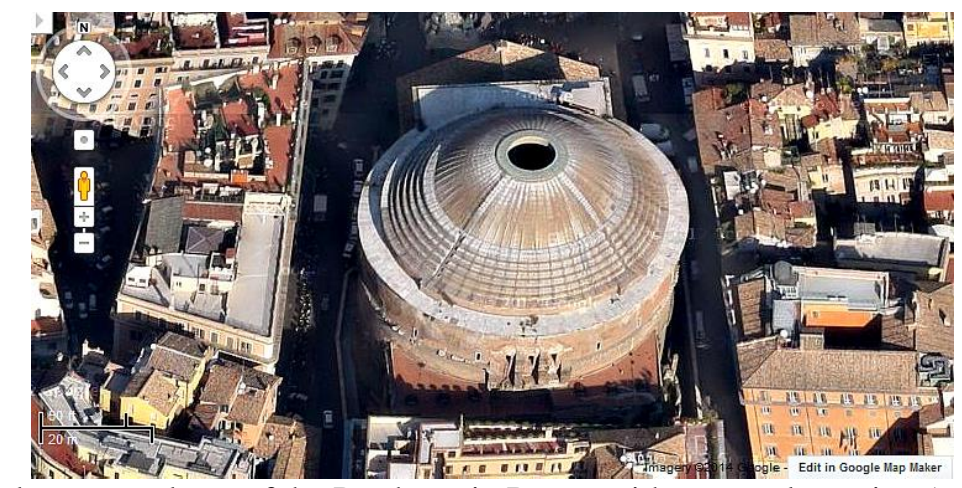

Figure 1 - The coffered concrete dome of the Pantheon in Rome, with a central opening (oculus) to the sky, as seen from satellite (courtesy: Google Maps). 
Vitruvius devoted a chapter of his book on Architecture to pozzolana [4]. He is telling the following. "There is a species of sand which, naturally, possesses extraordinary qualities. It is found about Baiae and the territory in the neighbourhood of Mount Vesuvius; if mixed with lime and rubble, it hardens as well under water as in ordinary buildings. This seems to arise from the hotness of the earth under these mountains and the abundance of springs under their bases". The
Vitruvius' pozzolana is the volcanic ash derived from the unconsolidated pyroclastic materials erupted by the Phlegraean Fields, Campi Flegrei, a volcanic field near Vesuvius (Fig.2). The Latin writer also describes accurately the hydraulic cement, the cement which hardens because of hydration, in reactions that occur independently of the mixture's water content, and therefore it is hardening underwater or exposed to wet weather.

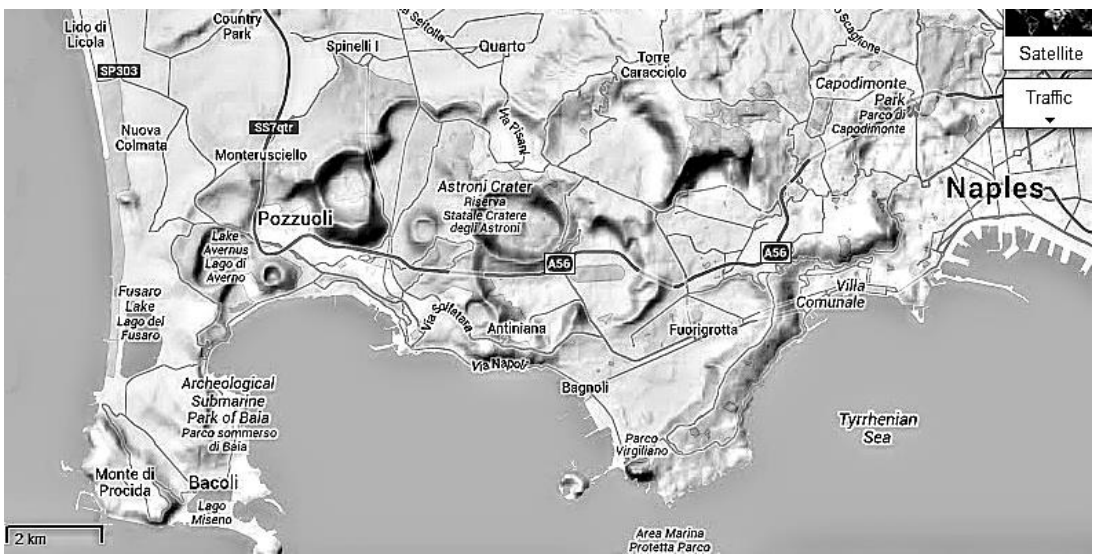

Figure 2 - The Phlegraean Fields in the Google Maps. Puteoli (Pozzuoli) is in these Fields.

Vitruvius continues: "it seems certain that the moisture is extracted from the sand-stone and earth in their neighbourhood, by the strength of the fire, as from limestone in a kiln. Dissimilar and unequal actions thus concentrated towards the same end, the great want of moisture quickly supplied by water binds and strongly cements them, and also imparts a rapid solidity". However, he notes that in Tuscany, where there are several hot springs too, "we do not there find a powder, which, for the same reason, would harden under water ... All lands do not possess similar qualities; nor is stone universally found. Some lands are earthy, others gravelly, others gritty, others sandy: in short, the quality of land, in different parts of the earth, varies as much as even the climate itself'. This means that in Rome there was a precise recipe for the hydraulic concrete, based on pozzolana, "pulvis puteolanus" in Latin, that is, the dust of Puteoli, the town in the Campi Flegrei.

Pliny in his Natural History describes cement and pozzolana too. First of all, he starts to discuss the Opus signinum [7] and its manufacture, as follows. "What is there that human industry will not devise? Even broken pottery has been utilized; it being found that, beaten to powder, and tempered with lime, it becomes more solid and durable than other substances of a similar nature; forming the cement known as the "Signine" composition, so extensively employed for even making the pavements of houses. But there are other resources also, which are derived immediately from the earth. Who, indeed, cannot but be surprised at finding the most inferior constituent parts of it, known as "dust" ("pulvis") only, on the hills about Puteoli, forming a barrier against the waves of the sea, becoming changed into stone the moment of its immersion, and increasing in hardness from day to day - more particularly when mixed with the cement of Cumae?" After these words, Pliny is also reporting information on some places where it is possible to find materials suitable for making cement. However, the Pliny's discussion ends with some rather fantastic reports.

\section{Formaceos walls}

Pliny, in his Natural History, also described the "formaceos walls", walls that can be found in Africa and Spain. He continues "And then, besides, have we not in Africa and in Spain walls of earth, known as "formaceoan" walls? From the fact that they are moulded, rather than built, by enclosing earth within a frame of boards, constructed on either side. These walls [8] will last for centuries, are proof against rain, wind, and fire, and are superior in solidity to any cement. Even at this day, Spain still beholds watchtowers that were erected by Hannibal, and turrets of earth placed on the very summits of her mountains". $\mathrm{He}$ is probably referring to the tapias [8-10], created with a mixture of lime, sand and gravel. This same lime-cemented material was used, during the 1520 s, to build the first palace of Cortés in Mexico City [10]. 
There is another reference to formaceos walls in a book on the "Rerum Rusticarum" written by Varro $[11,12]$. When Varro is discussing the fences used to mark the farm boundaries, he tells that fences can be masonry works too. "There are usually four varieties: those of cut stone, as in the country around Tusculum; those of burned brick, as in Gaul; those of unburned brick as in the Sabine country; those of gravel concrete, as in Spain and about Tarentum". Varro does not describe the components of the mortar used for these walls.

\section{Macedonian concrete}

We see then, from the Latin literatures, that the Romans never told they were the first to invent the concrete. Since the Romans used concrete extensively from $300 \mathrm{BC}$ to $476 \mathrm{AD}$, spanning more than seven hundred years [13], it is commonly believed that this material is a Roman invention. For this reason, in April 2011, in concurrence with an exhibition in the Oxford's Ashmolean Museum of some ancient treasures of Greece, BBC announced that it was discovered that Macedonians created cement three centuries before the Romans [14]. Unearthing some tombs of a royal complex belonging to Alexander the Great and his father Philip, at Vergina, archaeologists determined that Macedonians were "not only great warriors but revolutionary builders as well", since they used concrete before the Romans. This information is quite interesting because shows the location of an earlier use of concrete.

If we want to shed light on the origin of the material, this simple comparison between Macedonian and Roman concretes is not enough. Moreover, it is raising the following question: were Macedonians the first people using concrete? The answer is negative. Concrete is quite older than Alexander the Great as we will see continuing our discussion on Latin essays. Following an interesting note written by Fairfax Harrison in his book containing the treatises of Cato and Varro [12], we arrive to the concrete used in the Mycenaean palaces.

\section{The Mycenaean concrete}

Of the English translation of the Varro's book [12], the footnotes are quite remarkable. Who translated and wrote the notes was Fairfax Harrison (18691938). American lawyer, businessman and writer, he became in 1913 president of the Southern Railway Company. He was then an industrialist as well as the writer that translated the agricultural works of ancient Roman writers. Let us report the complete footnote about a Varro's sentence, because it is very important for our discussion. "The kind of fence which Varro here describes as "ex terra et lapillis compositis in formis", is also described by Pliny as formaceos or moulded, and he adds "aevis durant". It would thus clearly appear to have been of gravel concrete, the use of which the manufacturers of cement are now telling us, is the badge of the modern progressive farmer. Cato told how to burn lime on the farm, and these concrete fences were of course formed with lime as the matrix. When only a few years ago, Portland cement was first produced in America at a cost and in a quantity to stimulate the development of concrete construction, engineers began with rough broken stone and sand as the constituents of what they call the aggregate, but some one soon "discovered" that the use of smooth natural gravel made more compact concrete and "gravel concrete" became the last word in engineering practice. But it was older even than Varro. A Chicago business man visiting Mycenae picked up and brought home a bit of rubbish from Schliemann's excavations of the ancient masonry: lying on his office desk it attracted the attention of an engineering friend who exclaimed, "That is one of the best samples of the new gravel concrete I have seen. Did it come out of the Illinois tunnel?" "No," replied the returned traveller, "it came out of the tomb of Agamemnon!"

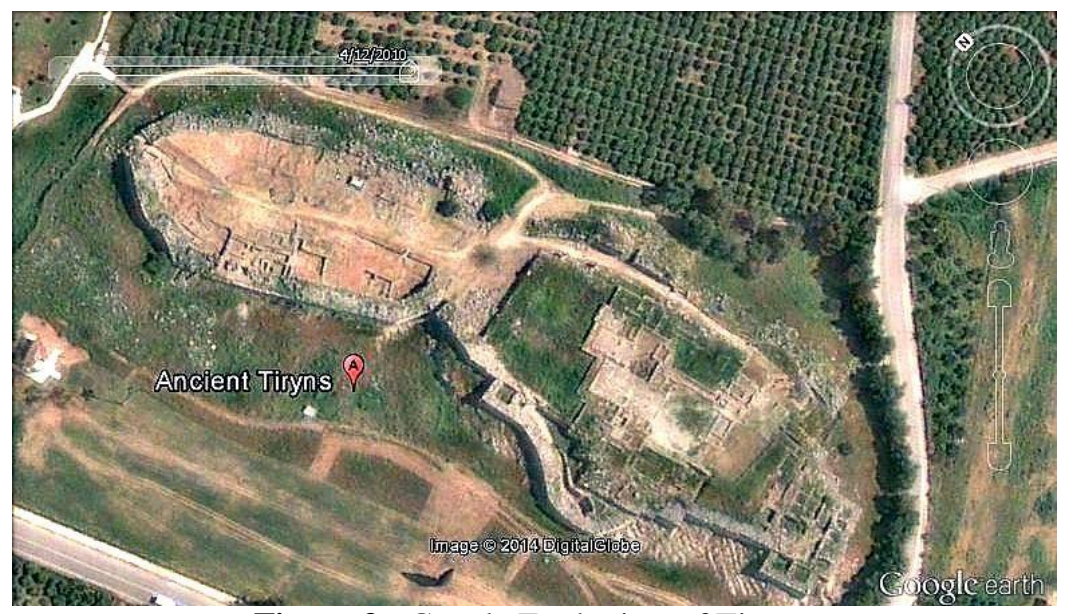

Figure 3 - Google Earth view of Tiryns. 
Really amazing this note written by Fairfax Harrison. It means that Mycenaean people knew and used concrete, before Romans, Carthaginians and Macedonians. Unfortunately, I was not able to find any other detail on the concrete, probably lost forever, of the tomb of Agamemnon. Therefore, I decided to find some hints in the available works written by Heinrich Schliemann, and I found where and for what the Mycenaeans used the concrete.

Besides his famous works at Troy and Mycenae, Schliemann started the excavation of Tiryns, a Mycenaean archaeological site in the Peloponnesus, some kilometers north of Nauplion. Tiryns was a hill fort occupied even before the Bronze Age (see Figure 3), which reached its height between 1400 and 1200 BC. The fort had a palace and cyclopean walls and tunnels. The detailed reports of the excavations of Tiryns are in a book [15]. There are several sentences in [15] concerning concrete, because people of Tiryns used the concrete for floors. The researchers write that, when excavating and cleaning of the citadel, they "cleared a part of the great gallery to the southeast, of which the upper part forms a pointed arch", and "found therein a floor formed of concrete" (Figure 4). Moreover, the archaeologists found that the "oldest houses of the primitive settlement" had floors that they found preserved in many places, floors that "were of beaten-down clay and in this quite different from the floor of the palace, built together with the Cyclopean walls on the upper citadel, for this is always of lime concrete".

However, the most interesting description is that of the floors of the men's court of the upper citadel. The book tells: "The floor of the court is composed of a strong concrete of small pebbles and lime, and even now produces a very fine effect. In the middle of the south side, immediately beside the northeast pilaster of the Propylaeum, stands a great altar built of quarried stones. It was apparently dedicated to Zeus, like the altar in the Palace of Odysseus. ... Through the Prothyra we enter a great court .... This is the men's court, the centre of the whole palace. The ground-plan is approximately a rectangle, not counting the depth of the colonnades. The whole floor is still covered with thick lime concrete, injured only here and there. In the great shaft at the northeastern corner of the court, which Dr. Schliemann sunk in 1876, the various strata of this concrete floor are plainly discernible. Lowermost on the remblai, there is a thick stratum $(40-70 \mathrm{~mm})$ of stones and lime, a sort of Beton, intended as a secure basis for the actual concrete; then follows a second layer about $15 \mathrm{~mm}$ thick, consisting of pebbles and a very solid reddish lime. Uppermost lies a layer of about $18 \mathrm{~mm}$ thick, made of lime and small pebbles, and affording a most durable concrete. In some places, especially in the east colonnade, repairs had already been made in ancient times, and with an inferior mortar, consisting almost exclusively of lime. The escape of rainwater is very carefully provided for, for the surface of the concrete is not a horizontal plane, but so levelled that the water runs off to a single point on the south side. There we find a vertical shaft, built of rubble, and covered with a stone flag. Through a hole in this covering stone, the water fell down the shaft, and so reached a walled horizontal canal, which probably led it to some reservoir. No trace of this reservoir, which must have been some metres below the floor of the palace, has yet been found; but its existence may with some confidence be assumed, since the inhabitants of the citadel would hardly have left the water gathered by the roofs and floors to be wasted".

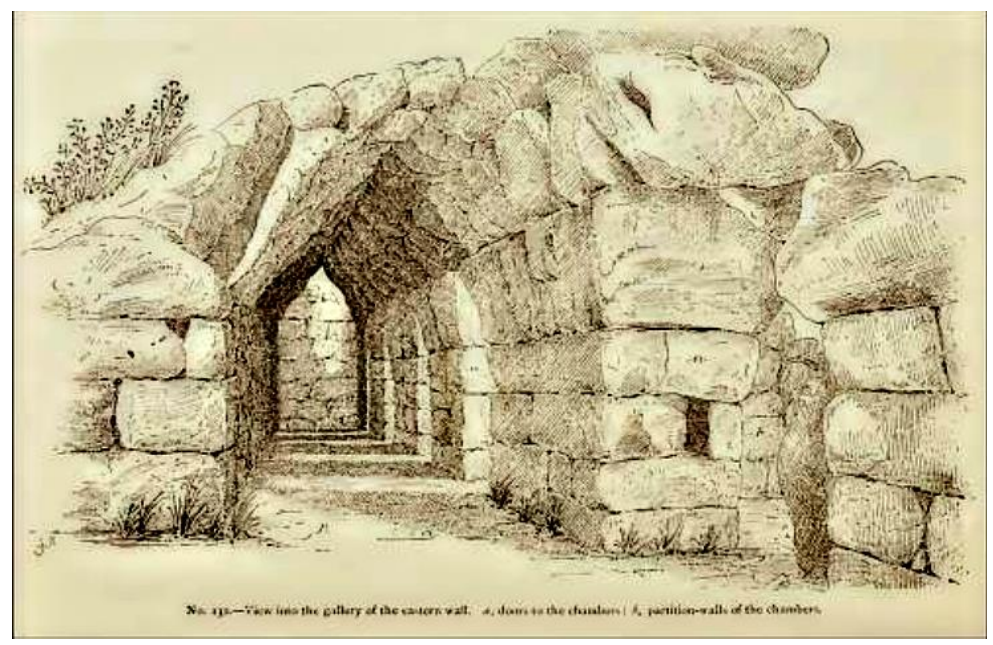

Figure 4 - A tunnel in the cyclopean walls of Tiryns [15].

\section{An Egyptian concrete}

We have seen that in Homeric times, Greeks used concrete for floors. Is it possible that other people of the Mediterranean Basin, such as the Egyptians for instance, used concrete? It seems that in early Egyptian pyramids constructed about 2600-2500 
BCE, the limestone blocks were bound by mortar of mud and clay, or clay and sand, and that in later Egyptian pyramids, the mortar was made of either gypsum or lime $[16,17]$. However, besides the use of mortar, had Egyptians created their concrete too?

Europhysics News, the magazine of the European physics community, published in 2009 an interesting paper revisiting the construction of the Egyptian pyramids [18]. In this paper, it is told that, in 1978, the French chemist Joseph Davidovits, rejecting the generally accepted hypothesis that the Giza pyramids were made by the technique of carving and hoisting stones, proposed a building method involving the moulding of blocks on site. Then, according to Davidovits, the blocks were made of a concrete whose basic binding compound was natron, a sodium carbonate extracted very close to the site of Giza, well-known by the Egyptians that used it for their blue-glaze ornamental statues [19]. The material obtained after chemical reactions is a geopolymer, a name given by Davidovits to it. Therefore, Davidovits proposed that the Giza builders had pulverized limestone and mixed it with water and natron. Natron, lime and water form caustic soda, which reacts with aluminous limestone to yield the basic geopolymer.

In Reference 18, there are reported some data from $\mathrm{X}$-ray fluorescence and X-ray diffraction that have shown some blocks of pyramids consisting of limestone (85 to 92\%) associated with a binder. Additional analyses were performed by PIXE (Particle-Induced X-ray Emission), PIGE (ParticleInduced gamma-ray Emission) and by NMRSpectroscopy for structural characterization. One of the pyramid's samples appeared to be made of a central compact structure embedded in a material of different composition. The central part is natural limestone but the outer part contains a large amount of $\mathrm{F}, \mathrm{Na}, \mathrm{Mg}, \mathrm{Al}, \mathrm{Si}$ [18]. These results seem in agreement with the fact that the ancient Egyptian had their concrete and used it in building pyramids.

The Davidovits' proposal is not accepted by mainstream archaeologists [20], namely, that some of the blocks of the Great Pyramids of Egypt might have been cast from synthetic material, not carved from quarries. As told in [20], archaeologists say there is simply no evidence that the pyramids are built of anything other than huge limestone blocks, and any synthetic material showing up in tests is probably coming from repairs done over the centuries. However, the Davidovits' hypothesis can be tested by using geophysical methods; one of them is the analysis of magnetization. Recently, in Reference 21, some data on the paleomagnetism of the materials of Khufu and Khafre pyramids had been published. The aim of the research was to find out the directions of the magnetic polarization vectors of the building blocks, because this is one of the possible ways to verify if the blocks were produced in situ by a concrete technique [21]. The analysis of a limited set of samples provided that the paleodirections of three sampling locations exhibit a common north-south orientation, suggesting that they may have been made in situ as proposed by Davidovits. However, blocks of natural limestone coming from the adjacent quarry exist. Then, the authors in Reference 21 conclude that "even if the concrete technique was used, the pyramids were constructed from a mixture of natural and artificial limestone blocks".

\section{The Galilee concrete}

Probably, the earliest known concrete is that found at Yiftahel, in the Southern Galilee. The archaeologists found there several concrete floors that were cast over time in one of the buildings by a Pre-Pottery Neolithic Part B (PPNB) culture, 9800 years ago. These discoveries tell that the use of concrete is actually predating the invention of pottery made from clay and the use of metal for making tools [22]. Then, we can tell that "before there was pottery or metal, there was concrete" [22].

Yiftahel is located about 5 miles west of Nazareth. It was discovered in 1982 when a bulldozer struck unearthed ancient buildings while excavating for a new highway. This site is likely the oldest permanent village ever found. It was of the PPNB culture that used rock and mud to construct walls and concrete for the floors. "The buildings were rectangular, and aligned to true north, indicating that the inhabitants developed some knowledge of how to do layout work" [22]. The researches by several scholars for the past 25 years revealed some information about the concrete. Basically, this material is lime-concrete. "Wood-fired kiln temperatures achieved at this point in human history were between $850^{\circ}$ to $900^{\circ} \mathrm{C}$, sufficient to calcine limestone to make lime, but not enough to fire clay pottery or to produce hydraulic cements" [22]. In any case, the discovery of Yiftahel revealed "an organized technological society that developed an industry to produce the lime cement and to construct the concrete floors" [22].

\section{Conclusion}

As we have seen, cement and concrete are older than Rome. The excavation of Yiftahel showed that concrete was used at least 9800 years ago, quite before people were able to make pottery or use metals for tools. In the paper, we have also discussed the concrete found in the Greek palaces of Homeric times, and that of the Egyptian pyramids. Probably, even before the Bronze Age, many cultural patterns ran across the Mediterranean basin, spreading the knowledge of materials and building techniques. And, on this network of knowledge, we can imagine 
the use of ancient cement and concrete, moving from the Middle East to the ancient Greece and then to Rome.

\section{References}

[1] A.C. Sparavigna, Materials Science in Ancient Rome, arXiv: 1107.3831

[2] A.C. Sparavigna, Ancient Concrete Works, arXiv:1110.5230

[3] Marcus Vitruvius Pollio (born c.80-70 BC, died after c.15 BC) was a Roman architect and engineer, active in the 1st century BC. He is best known as the author of the "De Architectura". By his own description, Vitruvius served as a ballista (artilleryman), in the army. He likely served as senior officer of artillery. Gaius Plinius Secundus (23 AD - August 25, 79 AD), known as Pliny the Elder, was a natural philosopher, as well as a naval and army commander of the early Roman Empire. He was a personal friend of the emperor Vespasian. Spending most of his spare time studying, writing or investigating natural and geographic phenomena, he wrote his encyclopedic work, the "Naturalis Historia". Pliny died on August 25, $79 \mathrm{AD}$, during the eruption of Mount Vesuvius that destroyed the cities of Pompeii and Herculaneum.

[4] Marcus Vitruvius Pollio, The Architecture, Translated by Joseph Gwilt, Priestly and Weale, London, 1826.

[5] Pliny, The Natural History, Translated by John Bostock and H.T. Riley, Henry G. Bohm, London, 1857.

[6] M. Jackson, L. Sagnotti, P. Rochette and P. Sølheid, Maintaining Standards III, Pozzolana Cement, The IRM Quartely, Fall 2003, Volume 13, Issue 3, Pages 1-12.

[7] Opus signinum is a building material occasionally used in ancient Rome. The technique to create this material was developed in North Africa, sometime before $256 \mathrm{BC}$, and spread north from there to Sicily and finally to the Italian peninsula. Floors of signinum are found extensively in the Punic towns of North Africa and commonly in the Hellenistic houses on Sicily. The use of signinum in Rome began in the 1 st century $\mathrm{BC}$, proliferating in private homes as well as public buildings. See for instance, en.wikipedia.org/wiki/Opus_signinum,

it.wikipedia.org/wiki/Cocciopesto

[8] A note in Reference 5 is telling that "Ajasson says that they are called tapias at the present day in Spain".

[9] Vv. Aa., es.wikipedia.org/wiki/Tapial

[10] A.B. Murphy, D.L. Johnson and V. Haarmann, Cultural Encounters with the Environment: Enduring and Evolving Geographic Themes, Rowman \& Littlefield, 2000.

[11] According to Wikipedia, Marcus Terentius Varro (116 BC 27 BC) was a scholar and writer that studied under the Roman philologist Lucius Aelius Stilo, and later at Athens under the Academic philosopher Antiochus of Ascalon. Varro was a highly productive writer on a variety of topics. One of his books is on the Rerum Rusticarum.

[12] Fairfax Harrison, Roman Farm Managements: The Treatises of Cato and Varro Done in English, with Notes of Modern Instances. Belvoir, Fauquier County, Virginia, 1918.

[13] MAST, University of Illinois, The History of Concrete, online resource.

[14] BBC, Macedonians Created Cement Three Centuries before the Romans, www.bbc.co.uk/ news/world-europe-13046299

[15] Heinrich Schliemann, Felix Adler and Wilhelm Dörpfeld, Tiryns: The Prehistoric Palace of the Kings of Tiryns, the Results of the Latest Excavations, Scribner's Sons, 1885.

[16] Vv.Aa., en.wikipedia.org/wiki/Mortar_(masonry)

[17] M. Isler, Sticks, Stones, and Shadows: Building the Egyptian Pyramids, University of Oklahoma Press, 2001.

[18] G. Demortier, Revisiting the Construction of the Egyptian Pyramids, Europhysics News, 2009, Volume 40, Issue 1, Pages 2731.

[19] A.C. Sparavigna, Faience: the Ceramic Technology of Ancient Egypt, Archaeogate, 12 February 2012.

[20] C. Nickerson, Did the Great Pyramids' builders use concrete? The New York Times, April 23, 2008.
[21] I. Túnyi and I.A. El-hemaly, Paleomagnetic Investigation of the Great Egyptian Pyramids, Europhysics News, 2012, Volume 43, Issue 6, Pages 28-31.

[22] H. Kanare, I. Milevski, H. Khalaily, N. Getzov and J. Nasvik, How Old is Concrete?, Concrete Construction, January 2009. 